www.periodicos.unimontes.br/index.php/caminhosdahistoria

\title{
EDWARD PALMER THOMPSON E A ECONOMIA MORAL DAS MULTIDÕES LATINO-AMERICANAS ${ }^{1}$
}

\author{
Carlos Antonio Aguirre Rojas ${ }^{2}$
}

Recebido em: 20/04/2020

Aprovado em: 11/06/2020

Resumo: Este ensaio pretende ser uma tentativa de aplicação criativa do rico e complexo conceito desenvolvido por E. P. Thompson, 'a economia moral da multidão', no caso particular das recentes mobilizações, protestos e movimentos desenvolvidos na América Latina no último quarto de século. Então, depois de tentar, inicialmente, definir, de forma rigorosa, o dito conceito thompsoniano, passa-se, posteriormente, a analisar, a partir dos conteúdos da dita 'economia moral', aos principais movimentos anti-sistêmicos latinoamericanos atuais e, entre eles, o neozapatismo mexicano, o movimento Mapuche, do Chile, o Movimento dos Sem Terra, do Brasil, os movimentos dos piqueteros argentinos, o movimento da CONAIE equatoriana, ou o Movimento Pachakutik da Bolívia, entre outros. Além disso, e sempre a partir da ferramenta intelectual representada pelo conceito cunhado por Thompson, trata-se de explicar e caracterizar a recente mobilização geral de todo o povo equatoriano, em outubro de 2019, à greve nacional colombiana, em novembro de 2019, e à vasta, e ainda hoje ativa, mobilização do povo insurgente chileno, iniciado em 18 de outubro de 2019.

Palavras-chave: Economia moral; multidão; América Latina; movimentos anti-sistêmicos; protesto popular.

\section{EDWARD PALMER THOMPSON Y LA ECONOMIA MORAL DE LAS MULTITUDES LATINOAMERICANAS}

Resumen: Este ensayo pretende ser un intento de aplicación creativa del rico y complejo concepto elaborado por E. P. Thompson, 'la economía moral de la multitud', al caso particular de las recientes movilizaciones, protestas y movimientos desarrollados en América Latina en los últimos cinco lustros transcurridos. Entonces, después de intentar inicialmente definir de manera rigurosa dicho concepto thompsoniano, se pasa después a analizar, desde los contenidos de dicha 'economía moral', a los principales movimientos antisistémicos latinoamericanos actuales, y entre ellos, al neozapatismo mexicano, al movimento mapuche de Chile, al Movimiento de los Sin Tierra de Brasil, a los movimientos piqueteros argentinos, al movimiento de la CONAIE ecuatoriana, o al Movimiento Pachakutik de Bolivia, entre otros. También, y siempre desde la herramienta intelectual que representa el concepto acuñado por Thompson, se trata de explicar y de caracterizar a la reciente movilización general de todo el pueblo ecuatoriano de octubre de 2019, al Paro Nacional colombiano de

\footnotetext{
${ }^{1}$ Tradução de Ester Liberato Pereira - Professora do Programa de Pós-Graduação em História. Universidade Estadual de Montes Claros - MG, Brasil.

${ }^{2}$ Doutor em Economia pela Universidad Nacional Autónoma de México (UNAM); Pós-doutor em História pela École des Hautes Etudes en Sciences Sociales de Paris, França. Pesquisador efetivo nível 'C', em tempo integral, no Instituto de Investigaciones Sociales da Universidad Nacional Autónoma de México. E-mail: aguirrec@unam.mx.
} 
noviembre de 2019, y a la vasta y aún hoy activa movilización del insurrecto pueblo chileno, iniciada el 18 de octubre de 2019.

Palabras clave: economía moral; multitud; América Latina; movimientos antisistémicos; protesta popular.

\title{
EDWARD PALMER THOMPSON AND THE MORAL ECONOMY OF LATIN AMERICAN CROWDS
}

\begin{abstract}
This essay is intended to be an attempt to creatively apply the rich and complex concept developed by E. P. Thompson, 'the moral economy of the crowd', in the particular case of the recent mobilizations, protests and movements developed in Latin America in the last quarter of a century. So, after trying, initially, to define, rigorously, the so-called Thompsonian concept, we then proceed to analyze, from the contents of the so-called 'moral economy', the main current Latin American anti-systemic movements and, among them, the Mexican neozapatism, the Mapuche movement, from Chile, the Movement of the Landless, from Brazil, the movements of the Argentine piqueteros, the movement of the Ecuadorian CONAIE, or the Pachakutik Movement of Bolivia, among others. In addition, and always based on the intellectual tool represented by the concept coined by Thompson, it is a question of explaining and characterizing the recent general mobilization of the entire Ecuadorian people, in October 2019, the Colombian national strike, in November 2019, and the vast, and still active, mobilization of the Chilean insurgent people, which began on October $18^{\text {th }}, 2019$.
\end{abstract}

Keywords: Moral economics; crowd; Latin America; anti-systemic movements; popular protest.

\section{Sobre a riqueza do conceito de "economia moral da multidão"}

Como se sabe, o agora famoso e difundido conceito de "economia moral da multidão" foi cunhado e introduzido no debate acadêmico de historiadores e cientistas sociais por Edward Palmer Thompson que, em 1971, publicou, na Edição 50 da revista Past and Present, seu ensaio intitulado "A economia moral da multidão inglesa no século XVIII". Assim, e mais precisamente especificando esse termo, o qual ele já havia usado em 1963, em seu grande trabalho sobre A formação da classe operária inglesa, Thompson formalizou e deu à luz um conceito que, ao longo dos anos, se tornaria o conceito mais discutido, adotado, conhecido e citado, mas também o mais deformado, vulgarizado e mal interpretado, dentro do conjunto de todos os conceitos incluídos no vasto e complexo universo do importante legado intelectual thompsoniano.

Pois depois de 1971, e desde o seu surgimento, esse conceito de economia moral da multidão começou a ser debatido em relação ao seu verdadeiro significado e suas possíveis implicações principais, ao mesmo tempo em que se multiplicaram os diferentes esforços para aplicá-lo, recuperá-lo e usá-lo, como uma ferramenta explicativa de processos e realidades de todos os cantos do planeta, implantada no período dos últimos cinco séculos e em 
praticamente todas as sociedades capitalistas possíveis. Isto, então, e dada essa enorme expansão e universalização do conceito, levou o próprio Edward P. Thompson a retomá-lo e refazê-lo, pela segunda vez, no ano de 1991, em seu novo ensaio agora intitulado "A economia moral revisada", incluindo em seu importante livro intitulado Costumes em comum $^{3}$.

E, mesmo após a segunda recuperação realizada por Edward Palmer Thompson, em 1991, esse conceito continuou "viajando pelo mundo", para continuar com as mais diversas projeções e adaptações, aumentando ainda mais sua popularidade e presença no discurso atual de historiadores e analistas sociais críticos contemporâneos.

Assim, e sem entrar na análise das interpretações muito diferentes e heterogêneas que foram dadas a esse conceito e de suas implicações teóricas e conceituais mais relevantes, pensamos, no entanto, que vale a pena lembrar os conteúdos centrais que, em nossa opinião, permitem propor uma definição mais rigorosa e, acima de tudo, mais alinhada com toda a obra e vida de E.P. Thompson, sobre o que é essa "economia moral da multidão".

E o mesmo, segundo nós, pode ser concebido como o conjunto de forças e mecanismos de regulação e autorregularão que, estabelecidos a partir da ética e da moral populares - não da ética cristã, mas dos códigos da vasta e rica cultura popular -, estabelecem uma barreira. Esta se dá dentro do conflito milenar da luta entre as classes sociais antagônicas, podendo estabelecer o que pode ser considerado como uma ação correta e uma já incorreta, ou seja, quais ações das classes dominantes e dos poderosos ainda são aceitáveis. No entanto, também estabelece as ações que, por sua vez, são intoleráveis, para determinar, no momento do colapso do pacto social entre essas classes antagônicas, ou na situação do colapso do equilíbrio social dentro das próprias classes populares, os objetivos, a lógica do comportamento e as formas em geral das ações concretas da multidão, ou seja, do conjunto de classes, setores e grupos subalternos de uma determinada sociedade ${ }^{4}$.

Bem, pretendemos estender, aqui, o mesmo espírito de maturação thompsoniana desse conceito, que deriva de tê-lo concebido como um instrumento teórico que nos permitiu

\footnotetext{
${ }^{3}$ Para reconstruir com mais cuidado esse itinerário complexo de evolução e amadurecimento progressivo deste conceito thompsoniano crucial de "economia moral da multidão", vale a pena comparar as várias definições dele e os argumentos para seu significado e implicações, contidos nos textos de Edward Palmer Thompson, que são $A$ formação da classe operária na Inglaterra, Ed. Crítica, 2 volumes, Barcelona, 1989, volume I, cap. 3, "As fortalezas de Satanás", pp. 51-61; "A economia moral da multidão na Inglaterra do século XVIII" e "A economia moral revisada", as duas últimas incluídas nos capítulos 4 e 5 do livro Costumes em comum, Ed. Crítica, Barcelona, 1995.

${ }^{4}$ Para uma base ampla e detalhada dessa redefinição que propomos do conceito de economia moral da multidão e das diversas implicações provocadas, cf. nosso ensaio, Carlos Antonio Aguirre Rojas, "Edward Palmer Thompson e a 'economia moral da multidão' no mundo do século XXI", no livro Pensadores críticos del 'longo século XX', Ed. Public University, de El Alto, El Alto, Bolívia, 2018.
} 
explicar apenas os "Motins de Fome" na Inglaterra do século XVIII. A partir disto, alçou voo e foi transformado em um conceito essencial para explicar as diferentes ações de protesto e resistência da multidão inglesa nos séculos XVIII e XIX. Passou a ser concluído, posteriormente, com sua elaboração e abertura mais universal, como uma ferramenta conceitual referente aos mecanismos subjacentes às diferentes formas de protesto e à ação social das multidões, em diferentes países e continentes, e nos diferentes séculos e momentos de toda a história capitalista. Tal maturação, assim, foi realizada pelo autor deste conceito crucial de 'economia moral da multidão'. Em nosso caso, gostaríamos de continuar e explorálo como uma ferramenta conceitual ainda relevante para a análise de certas realidades e processos implantados nesse incipiente terceiro milênio cronológico e dentro do espaço específico do semi-continente latino-americano.

Visto que, se concordarmos com E.P. Thompson, no objetivo de que esse conceito de economia moral da multidão deve "regenerar-se continuamente como uma crítica anticapitalista e como um movimento de resistência" ${ }^{5}$, é necessário e legítimo, então, continuar testando suas diversas aplicações. Estas, com base nas inevitáveis variações do contexto de cada novo caso ou situação pesquisada, permitirão continuar a qualificar, enriquecer e refinar esse conceito central, nascido da caneta do autor do grande livro $A$ formação da classe operária inglesa.

\section{A economia moral das multidões latino-americanas}

Se observarmos cuidadosamente a situação em que a América Latina vive, nos últimas vinte e cinco ou trinta anos, e tentarmos analisá-la a partir de várias arestas que nos permitem revelar e descobrir esse conceito complexo de 'economia moral da multidão', chamar-nos-á a atenção, de imediato, o fato de que durante esse período mencionado, testemunhamos, em toda a extensão e amplitude de nosso semi-continente latino-americano, toda uma série de processos poderosos e recorrentes de vasta mobilização social, isto é, de evidente irrupção histórica vigorosa das ações de protesto e rebelião das multidões latino-americanas e, com elas, de uma clara atualização e manifestação da economia moral subjacente dessas mesmas multidões plebeias. O que, em 2011, parecia generalizar-se também em escala planetária ou semiplanetária, logo passou a apresentar-se de forma um tanto difusa e indeterminada.

\footnotetext{
${ }^{5}$ Esta afirmação é feita por E. P. Thompson em seu ensaio "A economia moral revisada", já mencionado acima e incluído no livro Costumes em comum, citado, p. 383.
} 
Vastas mobilizações sociais que, no caso latino-americano, abrangem desde as pacíficas 'Revoltas Indígenas', as quais, literalmente, inundam a cidade de Quito, no Equador, como no caso das 'Revoltas' das décadas de 1990 e 2000; até Marchas simultâneas de protesto, que viajam centenas ou milhares de quilômetros e atravessam diversos estados e cidades para desembocar na capital, como no caso das Marchas de 1997, 2005 e 2018, em direção a Brasília, realizadas pelo Movimento dos Trabalhadores Rurais Sem Terra do Brasil; e passando pela revolta digna dos indígenas neo-zapatistas mexicanos de $1^{\circ}$ de janeiro de 1994, ou pela sua impressionante Marcha da Cor da Terra, em 2001; ou pelos bloqueios e paralização não apenas das cidades irmãs e simbióticas de La Paz e a cidade de El Alto, mas de toda a Bolívia, implantada em mais de oitenta pontos em todo o território boliviano, por meio de cortes e bloqueios de estradas e cidades, executados pelos indígenas aimarás, por exemplo, em maio e junho do ano de 2005, ou no segundo semestre de 2019, entre muitos outros exemplos possíveis.

Leque multicolorido e diversificado de mobilizações sociais vigorosas que, respondendo às queixas e ataques das diferentes classes dominantes da América Latina, conseguiram, muitas vezes, derrubar governos locais, estaduais e até nacionais. Ao mesmo tempo, desencadeavam crises políticas reais, também nacionais, e que geram, fortalecem ou consolidam movimentos sociais anticapitalistas e anti-sistêmicos cada vez mais poderosos. Novos movimentos sociais latino-americanos robustos, amplos e poderosos, que não têm equivalentes em termos dessa força e papel social forte e maciço, e em termos de sua persistente permanência, nem nos Estados Unidos, nem na Europa, nem na Ásia, na África ou na Oceania, constituindo, então, o espaço da América Latina, como a vanguarda mundial atual de todo o vasto grupo da família de lutas anti-sistêmicas e movimentos anticapitalistas de todo o planeta ${ }^{6}$.

Porque, embora fique claro que o protesto social e a vasta mobilização popular se multiplicaram e proliferaram em todo o mundo nos últimos vinte e cinco anos, também é evidente que é no espaço do semi-continente latino-americano que essa mobilização e esse protesto adquiriram suas formas de manifestação mais radicais e anti-sistêmicas. É também neste referido espaço que suas figuras mais permanentes estruturaram-se, dando origem a movimentos anticapitalistas poderosos e estabelecidos que sobrevivem e resistem

\footnotetext{
${ }^{6}$ Sobre esta situação atual, de intensa rebelião e grande desenvolvimento dos novos movimentos anti-sistêmicos na América Latina, e sobre o contexto mais geral dessa recente situação latino-americana, cf. Carlos Antonio Aguirre Rojas, América Latina en la encrucijada, Ed. Contrahistorias, 7 a edição, México, 2009; América Latina. História e presente, Ed. Papirus, São Paulo, 2004; Movimenti antisistemici. Pensare un'alternativa no XXI secolo, Ed. Aracne Editrice, Roma, 2013; Antimanuel du bon rebelle, Ed. L'Harmattan, Paris, 2015; e Movimientos antisistémicos y cuestión indígena en América Latina, Ed. Quimantú, Santiago do Chile, 2018.
} 
vitoriosamente aos diferentes ataques de suas respectivas classes dominantes. Ao mesmo tempo, já estão começando, aqui e agora, a criar novos mundos não capitalistas, sem exploração econômica, sem domínio político, sem opressões sociais e sem hierarquias absurdas de todos os tipos.

O que, por outro lado, e infelizmente, parece não ter acontecido, por exemplo, com toda a vasta família das rebeliões do emblemático ano de 2011, nem com outras grandes mobilizações sociais subsequentes, que depois de atingirem um clímax muito alto em termos de consenso social massivo, e também de ter vencido vitoriosamente certas demandas profundas e sinceras dos setores subalternos, os quais parecem ter fluido, sem deixar movimentos sólidos, estruturados e estáveis, ou, pelo menos, agentes sociais bem estabelecidos, mais permanentemente organizados para a ação e para a luta. Felizmente, no caso da América Latina e de seus múltiplos e diversos movimentos anti-sistêmicos atuais, parece que foram deixados movimentos consistentes e agentes sociais bem constituídos e aparelhados.

Maior permanência e estruturação mais sólida desses movimentos anticapitalistas e anti-sistêmicos da América Latina; não por acaso, isso explica tanto o fato de que importantes iniciativas quanto a organização dos Fóruns Sociais Mundiais (hoje em claro processo de declínio e crise, embora antes e, sobretudo, no início, um ponto de encontro global ativo e muito poderoso para os mais diversos movimentos anticapitalistas), tenham nascido e crescido, especialmente, nessas mesmas terras latino-americanas, além do fato de que as principais experiências e avanços desses novos movimentos anti-sistêmicos latino-americanos sejam, até hoje, observadas, estudadas, seguidas e investigadas, de perto, por ativistas, estudiosos e militantes de todos os movimentos sociais do resto do planeta.

Então, quando observamos a história recente de nossa América Latina, comprovamos que, em termos gerais, o termômetro da economia moral da multidão latino-americana tem aumentado lentamente, mas firmemente, nos últimos cinquenta anos. Isso, principalmente, pelo que representou, em terras latino-americanas, essa profunda ruptura histórico-universal que foi a revolução cultural mundial de $1968^{7}$. A elevação constante da "temperatura" geral da dita economia moral da multidão latino-americana atingirá seu ponto de ebulição conforme a medida do surto social e da ação direta e contundente da multidão, de maneira desigual e diferenciada, de acordo com as condições, a dinâmica e os eventos dos vários contextos

\footnotetext{
${ }^{7}$ Sobre esta revolução cultural mundial fundamental de 1968, cf. o livro La revolución cultural mundial de 1968, Ed. Desde Abajo, Bogotá, 2018, com textos de Fernand Braudel, Immanuel Wallerstein e Carlos Antonio Aguirre Rojas, entre outros. Além disso, cf. Immanuel Wallerstein, Giovanni Arrighi e Terence Hopkins, "1989, the continuation of 1968", em Review, vol. XV, não. 2, Binghamton, 1992.
} 
nacionais dos diferentes países da América Latina, que testemunhamos, muito claramente, ao longo da década dos anos 1990, e também dessas duas primeiras décadas do século XXI.

Porque, embora pensemos que é a economia moral de toda a América Latina que vem se aproximando, progressivamente, até o ponto de ruptura aberta do pacto social estabelecido entre as classes e setores antagônicos da sociedade, também é claro que esse processo geral qualifica-se e compassa-se de acordo com a trajetória específica de cada nação latinoamericana. Explodiu, assim, no México, em 1994, e na Argentina, em 2001; o mesmo que na Bolívia, em 2003, em 2005 e em 2019; no Equador, em 1997, em 2000, em 2005 e em 2019; no Chile e na Colômbia, no ano de 2011, e depois em 2019 e 2020; no Brasil, em 2013; e na Nicarágua, em 2018. Mas, pensamos que isso também poderá explodir muito, em breve, na Venezuela, no Peru ou no Paraguai, como também no México, Argentina ou Brasil, a partir de novos ataques e novas agressões e ofensas das respectivas classes dominantes e hegemônicas ainda subsistentes de todos esses países mencionados.

E isso porque, por trás dessa óbvia diversidade no amadurecimento singular de cada economia moral da multidão, em cada país latino-americano, parece claro que foi vivida a virada radical da revolução cultural de 1968 em todo o semi-continente. Este se estende de Rio Bravo à Patagônia, como um processo complexo que, ao revolucionar completamente o campo da cultura e, portanto, da cultura popular. E, ao ser, também, uma revolução total dos costumes, rompeu essas duas áreas, as quais, segundo o próprio Edward Palmer Thompson, são as principais fontes nutricionais que alimentam e determinam essa 'economia moral da multidão', ou seja, o espaço da rica e complexa cultura plebeia ou subordinada e, por outro lado, o variado e também multifacetado universo dos costumes ${ }^{8}$.

Mas se, em todo o mundo, a revolução cultural mundial de 1968 transformou a cultura e os costumes em suas raízes, essa mutação foi experimentada na América Latina, particularmente, primeiro como uma reavaliação e recuperação sistemática da referida cultura popular, ou plebeia, ou subordinada. E, em segundo lugar, como um processo claro de crescente politização de toda a vida cotidiana e do universo dos costumes, dessas mesmas classes e setores subordinados da sociedade.

\footnotetext{
${ }^{8}$ Sobre essa ideia de como a economia moral da multidão é nutrida e apoiada pela cultura e costumes populares, cf. o livro inteiro de E. P. Thompson, Costumes em comum, citado anteriormente, um livro que Thompson diz ser um conjunto de ensaios que pretendem ser "um único argumento estreitamente relacionado", conforme declarado no "Prefácio e Agradecimentos" do livro, p. 9. E sob essa luz, é surpreendente que os três capítulos que precedem o ensaio sobre a 'economia moral da multidão' abordem, precisamente, os temas da definição de cultura, das culturas plebeias e da patrícias, o conceito de costume, a articulação entre cultura e costume e a articulação, de maneira mais geral, de todos esses conceitos mencionados.
} 
Pois, se o 68 latino-americano colapsou as estruturas frágeis da cultura dominante em nosso semi-continente, estruturas nucleadas até essa data, em torno da imitação servil da cultura estadunidense, vazia e tecnocrática, e do modo de vida americano, também vazio, criou um vácuo cultural que, nas últimas cinco décadas, foi preenchido, em grande parte, com os elementos provenientes da sempre viva e ativa cultura plebeia ou subalterna. Aquela, que por mil vias e caminhos, conseguiu construir essas figuras semiautônomas, semi-subversivas, semi-toleradas e semipresentes, mas sempre muito criativas e inovadoras, que hoje constituem a cultura latino-americana em geral ${ }^{9}$. Figuras e formas culturais latino-americanas, fortemente impregnadas da cultura e do conhecimento popular que, consequentemente, também permitiram um ressurgimento e um claro fortalecimento da mencionada economia moral das multidões latino-americanas.

Por esse motivo, e para citar apenas um exemplo dentre os vários possíveis, não é por acaso que, após 1968, e como um de seus muitos efeitos saudáveis, tenha-se começado, na América Latina, o processo de reconhecimento verdadeiramente específico da identidade única de povos indígenas como tais, isto é, de sua identidade indígena não subordinada à identidade camponesa genérica, nem relegada ao universo marginal e desprezado do folclore, dos curiosos e exóticos, dos anedóticos e dos antropológicos. O reconhecimento de 'ser índio' como tal, que não apenas abriu o espaço para a formação e posterior afirmação dos poderosos e importantes movimentos sociais indígenas da América Latina de hoje, mas também e, como consequência, do $1^{\circ}$ de janeiro de 1994, de seu trânsito de uma postura defensiva e semimarginal, para uma nova posição, agora protagonista e claramente ofensiva. Algo que, entre muitos outros elementos, alimenta e, ao mesmo tempo, expressa, aqui, também, a 'economia moral' específica dos povos indígenas de toda a América Latina ${ }^{10}$.

Da mesma forma, e diante dos costumes excessivamente autoritários, tradicionais, conservadores e fechados que prevaleciam na América Latina até 1968, essa ruptura de eventos de cinco décadas atrás veio a sacudir e revolucionar todo esse campo do direito consuetudinário, a fim de desencadear um claro processo sustentado de liberalização dos

\footnotetext{
${ }^{9}$ Uma das muitas expressões dessa profunda mutação da cultura latino-americana e da forte presença, dentro dela, desses elementos da cultura popular, é a do surgimento do "boom literário latino-americano", que, precisamente, por volta de $68 \mathrm{em}$ diante, populariza na Europa, nos Estados Unidos e em todo o mundo, o "Realismo mágico latino-americano" e a literatura latino-americana em geral. Sobre esses pontos, cf. Alejo Carpentier, De lo real maravilloso latinoamericano, Ed. UNAM, México, 2004, e Carlos Monsiváis, Aires de familia: cultura y sociedad en América Latina, Ed. Anagrama, Barcelona, 2000. E no caso específico do México, cf. Carlos Antonio Aguirre Rojas, "La revolución mundial de 1968. Cuatro décadas después", em Contrahistorias, n. 11, México, 2008.

${ }^{10}$ Sobre este ponto, cf. Carlos Antonio Aguirre Rojas, "La cuestión indígena en México y en América Latina. Una visión desde la larga duración histórica", em Contrahistorias, n. 28/29, 2018, e Raúl Zibechi, Los desbordes desde abajo. 1968 en América Latina, Ed. Autodeterminación, La Paz, 2018.
} 
costumes e renovação das relações mais básicas das populações de toda a América Latina, gerando uma politização generalizada e onipresente de todas as dimensões da vida cotidiana, e uma afirmação crescente e também muito difundida entre os setores subordinados, de visões mais progressistas, tolerantes e críticas, e também potencialmente anti-sistêmicas de todos os problemas e questões sociais. Um processo que, mais uma vez, paga por essa nova presença e por uma maior recuperação da economia moral da multidão de cada nação latino-americana e da América Latina como um todo.

Algo que se torna evidente, por exemplo, no vasto e crescente movimento feminista das últimas cinco décadas, movimento que, graças à liberalização dos costumes e à politização da vida cotidiana mencionada, potencializou e promoveu o claro surgimento do atual protagonismo feminino rebelde. Este, se expressa em uma variedade complexa e multifacetada de posições feministas, que incluem desde algumas posições infundadas e irracionais, as quais, ao clamar pelo "empoderamento" das mulheres, fazem do "homem" seu suposto "inimigo" a ser superado, até outras concepções mais inteligentes e sutis, que assumem que o verdadeiro inimigo de homens e mulheres é o sistema capitalista, que recria e reproduz o absurdo esquema binário dos rígidos papéis sociais da suposta 'masculinidade' e da suposta 'feminilidade', que compõem a já anacrônica 'dominação masculina'. Um vasto movimento feminista latino-americano, que voltou a estar presente, no final de 2019, com a difusão mundial e com a adoção e readaptação diversa da performance 'O estuprador é você', inventada pelo grupo chileno de Las Tesis contra criminosos policiais carabineiros ${ }^{11}$, e essa é mais uma expressão da rica e multifacetada economia moral das multidões do nosso semicontinente.

E se essas profundas transformações, tanto no mundo dos costumes, quanto no das formas e figuras da cultura em geral e da cultura plebeia em particular, em todo o nosso semicontinente, são o pano de fundo compartilhado desse aumento de temperatura no termômetro da economia moral das multidões latino-americanas, suas várias formas de manifestação nacional, ilustram-nos, novamente, sobre a complexidade multifacetada de cada concretização histórico-singular dessa mesma economia moral da plebe. Bem, ao revisar os casos mencionados, do surto neo-zapatista de 1994, ou da série acompanhada pelos vários levantes indígenas equatorianos, ou das insurreições indígenas e populares na Bolívia, ou da rebelião dos piqueteros e subordinados argentinos do final de 2001, ou os vastos protestos no Brasil, contra a expansão explosiva do agronegócio e dos biocombustíveis, ou também a Copa do

\footnotetext{
${ }^{11}$ Sobre a origem dessa performance imaginativa e o significado de sua própria criação pelo grupo de teatro feminista chileno de Valparaíso chamado Las Tesis, cf. o jornal chileno The Clinic, de 5 de dezembro de 2019.
} 
Mundo de Futebol ou o Movimento Passe Livre, pelo transporte público gratuito, ou como nas muito recentes, e algumas ainda vivas, insurreições populares no Chile, Equador ou Colômbia, o que é óbvio é a multiplicidade de fatores que tiveram que ser combinados em cada um desses casos, a fim de desencadear tais surtos e amplas mobilizações sociais e, portanto, essa irrupção forte e evidente da economia moral da multidão de cada um desses países latino-americanos.

Explosões demonstrando que a economia moral da multidão, ou dos pobres, ou da plebe, nunca é determinada por um único fator, e nem mesmo por uma única ordem de coisas, sendo, pelo contrário, influenciada e determinada, simultaneamente, por causas e elementos econômicos, e também políticos, bem como sociais, culturais, geográficos, civilizacionais, antropológicos e um longo etc. ainda em aberto. E essa economia moral plebeia também não é definida por eventos correspondentes a uma única temporalidade, seja a imediata, ou a do tempo médio, ou a da longa duração, mas envolve, para sua maturação e eclosão, todos os tempos da história, todos os registros temporais tão intensamente estudados e classificados na época por Fernand Braudel ${ }^{12}$.

E se a economia moral não depende nem de um único fator ou nível de realidade, nem se limita a uma única temporalidade histórica e social, também não é desencadeada e libertada por uma única queixa ou ofensa das classes dominantes. Antes, é desatada por uma soma ou série de queixas e ataques que, em um dado momento, se condensam e se coagulam em um último ato ou situação que, funcionando como a gota que acaba derramando o copo, pressupõe e repousa, no entanto, sobre toda essa longa cadeia antecedente de ofensas, humilhações e arbitrariedades, às quais são sempre dadas as classes e setores hegemônicos, contra os subordinados oprimidos e sociais.

Complexidade e multideterminação da economia moral da multidão, o que é evidente nos diferentes casos mencionados acima. Por exemplo, na insurreição popular ainda viva e ativa do povo chileno, desencadeada em outubro de 2019 e que durou até hoje, permanecendo um pouco retraída e independente por enquanto, devido à situação de emergência mundial criada pela pandemia global da COVID-19. Insurreição profunda que eclodiu devido a um aparente evento menor, o aumento de trinta pesos chilenos ou quatro centavos de dólar no preço de uma passagem para o transporte público em Santiago do Chile, mas que foi

\footnotetext{
${ }^{12}$ Sobre essa teoria das diferentes temporalidades históricas, que tentamos conectar aqui com o conceito crucial da economia moral da multidão, cf. Fernand Braudel, "Historia y ciencias sociales. La larga duración", em Escritos sobre historia, Ed. Fondo de Cultura Económica, México, 1991, e Carlos Antonio Aguirre Rojas, Tempo, duração e civilização. Percursos Braudelianos, Cortez Editora, São Paulo, 2001, Braudel, o mundo e o Brasil, Cortez Editora, São Paulo, 2003, e Fernand Braudel e as ciências humanas, Editora da Universidade Estadual de Londrina, Londrina, 2003.
} 
basicamente a gota que encheu e transbordou o copo dos múltiplos erros cometidos por décadas pelos poderosos e pelos exploradores chilenos contra as classes subordinadas daquele país. É por isso que o povo chileno afirmou que "não são 30 pesos, mas 30 anos", aludindo às três décadas de governo após a atroz ditadura de Pinochet, que tornaram a educação chilena a mais cara do mundo, a mesma uma época em que privatizavam os serviços de saúde que, hoje, são muito caros e muito ruins, e atingiam tanto os salários quanto as aposentadorias de todos os trabalhadores e aposentados daquele longo país sul-americano.

Soma das queixas levadas a cabo pelos chamados 'governos da concertação', que também foram adicionadas às ofensas atrozes do período Pinochet, cuja herança ainda está viva demais e está presente em toda a vida e sociedade chilena, hoje, e onde não apenas abreviou e afogou em sangue a rica experiência de criação de poder popular que estava promovendo o MIR, mas também todas as conquistas de trabalhadores, camponeses e colonos urbanos que ocorreram ao longo do século XX. E até mais além, o surto popular chileno de 2019 e 2020 também coleta a memória das duradouras lutas do povo mapuche, que foram despidos, reprimidos, perseguidos e até 'trancados', literal e metaforicamente, dentro da ilusória nação chilena, embora nunca se conseguisse fazer com que desaparecessem, se submetessem ou se rendessem de qualquer maneira.

Com isso, essa medida aparentemente insignificante do aumento de 30 pesos serviu de gatilho para a reativação da economia moral de todas as multidões do Chile, somando-se aos mais recentes movimentos estudantis e feministas, assim como ao movimento operário, ao movimento camponês, à população urbana e ao combativo e avançado movimento indígena mapuche, em uma rebelião popular criativa e radical que, com os altos e baixos da natureza, é mantida viva e ativa, hoje, através de uma imensa malha de assembleias e conselhos de todos os tipos, que abrangem todo o território do estreito cinturão chileno e estão presentes em fábricas, universidades e campos, bem como em bairros, sindicatos e setores sociais nos campos da economia, cultura, política, sociedade e mesmo na vida cotidiana. Estruturas de assembleia criadas no calor dessa insurreição e que trabalham com os métodos de democracia direta, dentro de formas organizacionais horizontais, frouxas e anti-hierárquicas, muito semelhantes às que hoje desenvolvem todos os movimentos genuinamente anti-sistêmicos do mundo.

E se o povo insurgente chileno está autoprotegendo-se e protegendo-se da pandemia do novo coronavírus, diante da insensatez e ineficácia das medidas de seu governo desajeitado, eles também estão 'velando as armas' de seus novos combates muito próximos 
contra o sistema capitalista chileno e até global, combates que serão reativados assim que essa trágica emergência epidemiológica universal for superada ${ }^{13}$.

Outro exemplo claro da riqueza e polimorfismo da economia moral das multidões latino-americanas é o caso do neo-zapatismo mexicano, que também é explicado pelos desastres econômicos que anunciaram a entrada do México no Acordo de Livre Comércio da América do Norte, ou devido às mudanças regressivas no artigo 27 da Constituição contra a propriedade coletiva da terra. Estas atacaram uma das conquistas fundamentais da Revolução Mexicana, que, pelas razões culturais da ofensa simbólica, desejavam comemorar os quinhentos anos da invasão espanhola da América. Isto em um contexto de crescente e total racismo contra os povos indígenas em geral e contra os indígenas de Chiapas em particular, juntamente com as razões políticas da repressão política excessiva realizada por vários governos de Chiapas nas décadas de 1980 e 1990 do século passado, ou às causas legais do fechamento de leis e funcionários, locais, estaduais e federais, diante de pacientes e antigas reivindicações legais feitas pelos agricultores indígenas de Chiapas.

Embora também, e visto o problema dos horizontes de longa duração histórica, essa economia moral do digno povo indígena neo-zapatista mexicano também tenha sido nutrida pelo fato de que, durante quinhentos anos, eles resistiram com sucesso aos múltiplos ataques que tentaram impor o modelo da civilização capitalista ocidental vindo da Europa, que os espanhóis tentaram estabelecer com sangue e fogo entre todas as populações indígenas da América Latina. E se, naturalmente, os povos indígenas de Chiapas modernizaram-se sem dúvida alguma, o fizeram, no entanto, no âmbito de criar uma modernidade diferente da modernidade barroca capitalista dominante, uma modernidade de resistência a essa modernidade dominante, que manteve em vigor entre eles, por exemplo, a sábia ideia da 'mãe terra', ou também a predominância do coletivo 'nós' sobre o individual 'eu', ou, igualmente, a nítida não separação do social do político, e da validade das assembleias e da democracia direta, como mecanismo fundamental de governo e autogoverno das comunidades indígenas,

\footnotetext{
${ }^{13}$ Para entender melhor todas as arestas dessa insurreição chilena rebelde, ainda em andamento, vale a pena reler os principais textos do MIR chileno e, entre eles, os textos de Miguel Enríquez reunidos no livro Miguel Enríquez y el proyecto revolucionario en Chile. Discursos y documentos del Movimiento de Izquierda Revolucionaria, Coedição do Centro de Estudos Miguel Enríquez-Ed. LOM, Santiago do Chile, 2004, a brochura Chile. Movimiento de Izquierda Revolucionaria. Textos escogidos 1970-1975, Ed. Del MIR, Santiago do Chile, 1978, e En el camino del poder popular, panfleto n. 1 da "Serie del Poder Popular", Ediciones El Rebelde, Santiago do Chile, agosto de 1973. Ver também Gabriel Salazar, En el nombre del poder popular constituyente (Siglo XXI), Ed. LOM, Santiago do Chile, 2016, El poder nuestro de cada día, Ed. LOM, Santiago do Chile, 2016, e a entrevista "El tipo de Asamblea Constituyente que se propone, no representa realmente la voluntad soberana del pueblo", no jornal El Ciudadano, ano 15, n. 238, dezembro de 2019, pp. 4-6, e Carlos Antonio Aguirre Rojas, "Chile insurrecto en 2019 y 2020: el Derecho de Vivir en Rebeldía", em Contrahistorias, n. 33, 2020.
} 
entre outras características essenciais dessa diferente modernidade, antes de resistência e, hoje, uma alternativa à decadente modernidade capitalista ainda dominante ${ }^{14}$.

De modo que, quando com a assinatura do Acordo de Livre Comércio da América do Norte, as classes dominantes do México tentam impor com força e unilateralmente a 'modernização' forçada e a 'ocidentalização' irremissível de todas as populações indígenas do México (aquelas que, em conjunto, constituem cerca de $20 \%$ da população total do país). Assim, o que estão fazendo é um ataque frontal a esse projeto persistente e secular de modernidade indígena alternativa e, com isto, a um dos elementos importantes da história do México profundo, e também a um dos pilares de longa data da economia moral de todo o povo mexicano ${ }^{15}$.

Ou, também, o caso da insurreição popular argentina no final de 2001, que pode muito bem ser repetida em breve, devido à profundidade e nitidez da crise econômica pela qual o país está passando agora e que não será resolvida com as medidas reformistas mornas e socialdemocratas do governo limitado de Alberto Fernández; ao contrário, provavelmente, tornar-se-á mais aguda devido ao terrível contexto criado pela atual pandemia global da COVID-19. A insurreição de 2001 e 2002 foi desencadeada pela medida econômica injusta e ofensiva do "Corralito". Esta ocorreu devido à saciedade política dos cidadãos comuns diante de toda a classe política argentina, saciedade esta que, magistralmente, pôde ser sintetizada no lema legítimo “Deixe todos irem, deixem todos irem, e que não reste nenhum!”. Mas, ocorreu, também, devido aos múltiplos e desastrosos efeitos sociais causados pela década menemista de desindustrialização, desemprego e falência de empresas, juntamente com a queixa simbólica representada pela declaração do toque de recolher contra uma população civil que foi vítima de ineficiência do governo, e a proibição de sair de casa, absurdamente realizada por Fernando de la Rúa. Uma situação complexa que, de várias maneiras, se repetiu com o governo ineficaz e agressivo de Mauricio Macri, que desencadeou a desvalorização galopante do peso argentino e o aumento alarmante do desemprego, juntamente com a crise econômica geral já mencionada e, novamente, a crescente deslegitimização de toda a classe política argentina que, antes da última eleição presidencial de 2019, já havia levado a Argentina à

\footnotetext{
${ }^{14}$ Sobre as modernidades diferentes da modernidade capitalista, cf. Bolívar Echeverría, Las ilusiones de la modernidad, Ed. UNAM - Ed. The Equilibrista, México, 1995. Sobre a modernidade barroca da América Latina, cf. Bolívar Echeverría, La modernidad de lo barroco, Ed. Era, México, 1998. E sobre a modernidade alternativa do neo-zapatismo mexicano, cf. Carlos Antonio Aguirre Rojas, La modernidad de lo barroco, Editora Entremares, São Paulo, 2019.

${ }^{15}$ Sobre esses pontos mencionados, cf. o conjunto de textos incluídos no número 20 da revista Contrahistorias, de 2013, e também Carlos Antonio Aguirre Rojas, Chiapas, Planeta Tierra, Ed. Contrahistorias, 6a edição, México, 2010, Mandar Obedecendo. As lições políticas do neozapatismo mexicano, anteriormente citado, e Una tenera furia. Nuovi saggi sul neozapatismo mexicano, Ed. Aracne Editrice, Roma, 2019.
} 
beira de um surto social geral que, por enquanto, parece ter retornado, momentaneamente, ao estado adormecido.

Surto e protesto popular das classes subordinadas argentinas, nos anos de 2001 e 2002, que também envolvem, para sua adequada explicação, alguns elementos ou estruturas de longa duração, igualmente constitutivos da economia moral das multidões argentinas. E, em particular, o elemento da atitude do povo argentino em relação ao que poderíamos chamar de "direito histórico ao trabalho". Porque, quando há um desemprego maciço causado pelos dois governos de Carlos Menem, nos anos 1990, esse fenômeno é vivenciado, lá, como uma afronta exacerbada, muito mais difícil do que em outros países da América Latina, em uma nação que foi forjada a partir de fortes migrações europeias, de massas de pobres italianos, galegos, portugueses, húngaros, romenos, etc., que atravessaram todo o imenso Oceano Atlântico precisamente em busca de trabalho. Isto constrói, lentamente e durante décadas e séculos, algumas classes subordinadas argentinas que assumem esse trabalho como uma verdadeira conquista histórica e como um verdadeiro direito histórico.

Sorte intangível e não escrita, mas um "direito popular ao trabalho" muito real, que, em um país que concentra metade de sua população em sua capital (na chamada 'Grande Buenos Aires'), também constrói uma forte tradição de movimentos trabalhistas combativos e constantemente mobilizados. Estes, quando perdem seus empregos e ficam desempregados, em vez de se desmobilizar e recuar em suas vidas individuais, ou em vez de procurar individualmente novos empregos, como acontece em outros países da América Latina, optaram por criar os Movimentos dos Trabalhadores Desempregados (oximoro brilhante e inteligente, possível apenas nesta fase da crise terminal do capitalismo). Estes, em uma primeira etapa, formaram o Movimento Piquetero Argentino e que, mais tarde, acabaram se transformando no atual e interessante Movimento dos Bairros Piqueteros de todo aquele amplo espaço urbano que é o território da 'Grande Buenos Aires'.

Por esse motivo, quando De la Rúa decreta o "Corralito" e a desvalorização do peso argentino, é como se ele decretasse o fechamento maciço de milhares de empresas e a escalada excessiva desse desemprego e do fantasma dele, atacando com ele, no centro, esse "direito popular ao trabalho" intangível, mas muito vivo, um direito histórico de longa data que é centralmente constitutivo da 'economia moral das multidões' da Argentina ${ }^{16}$.

\footnotetext{
${ }^{16}$ Sobre estes, que foram os primeiros movimentos de piqueteros, e depois os bairros completos de piqueteros, cf. Miguel Mazzeo, Piqueteros. Breve historia de un movimiento popular argentino, Ed. Quadrata, Buenos Aires, 2014, Maristella Svampa e Sebastián Pereyra, Entre la ruta y el barrio. La experiencia de las organizaciones piqueteras, Ed. Biblos, 2a. edição, Buenos Aires, 2004, e Mariano Pacheco, De Cutral-Có a
} 
O que, então, no final de 2001, provocou a resposta espontânea e autoconvocada de todos os setores populares e subordinados da sociedade argentina, aqueles que saíram às ruas em massa, desafiando o governo De la Rúa e causando sua queda imediata. Ao mesmo tempo, e como resultado dessa mesma resposta, foi desencadeado um processo de auto-organização popular que povoou toda a cidade de Buenos Aires com centenas de Assembleias de Bairro e todos os perturbados e poderosos bairros de piqueteros auto-organizados da cidade, juntos a várias fábricas recuperadas e agora autogerenciadas. E foram essas figuras de organização popular construídas a partir de baixo, as assembleias de bairro, os bairros piqueteros e as fábricas recuperadas que derrubaram cinco presidentes argentinos em 2012 e criaram os sólidos e fortes movimentos anti-sistêmicos argentinos que, desde os últimos quinze anos até hoje, enfrentaram, e ainda enfrentam, os governos progressistas mornos dos Kirchners, ou o governo neoliberal selvagem e severo de Mauricio Macri, assim como o governo atual morno e limitado de Alberto Fernández.

Ou, também, o caso da Bolívia, onde o ciclo de explosões populares, que inclui a 'Guerra da Água', em 2000, a derrubada do presidente Gonzalo Sánchez de Losada, em 2003, a queda de Carlos Meza, em 2005, e o protesto popular contra a fraude eleitoral de Evo Morales, em 2019, só pode ser explicado se combinarmos uma longa série de queixas realizadas pelas classes dominantes bolivianas, que vão desde o desmantelamento progressivo de todas as conquistas da Revolução Popular de 1952, à entrega quase gratuita do gás boliviano aos Estados Unidos, passando pelos efeitos devastadores do neoliberalismo selvagem em um país que continua sendo um dos mais pobres da América Latina, ou pela criminalização absurda da produção e consumo ritual da folha de coca, juntamente com tentativas de privatização da água, ou o repetido racismo das elites brancas e sempre dominantes deste país, ou a clara zombaria do resultado do referendo de 2016, que se opôs à segunda reeleição de Evo Morales, entre muitos outros dos sucessivos e repetidos delitos dessas classes hegemônicas bolivianas, contra os grupos e classes subordinadas dessa mesma nação.

O mencionado ciclo de explosões sociais, que é uma expressão do claro descontentamento popular do povo boliviano e do surgimento de sua economia moral específica que, inicialmente, levou à eleição dos governos sucessivos de Evo Morales que se desenvolveram entre 2006 e 2019, mas que, mais tarde, também o confrontou, com base na clara fraude eleitoral de 2019 e na crescente e acumulada decepção que o povo boliviano

Puente Pueyrredón. Una genealogía de los Movimientos de Trabajadores Desocupados, Ed. El Colectivo, Buenos Aires, 2010. 
estava cultivando diante do reformismo e das evidentes limitações desses sucessivos governos de Morales, totalmente pró-capitalistas e tendenciosos apenas em benefício da burguesia nacional boliviana, mas não de seus vastos setores e classes populares e subordinadas. Um descontentamento que, sob esses governos, parecia ter se fragmentado, localizado e diminuído um pouco, devido à clara cooptação que eles fizeram de certas demandas populares e também pelas políticas social-democráticas mornas que eles implantaram nos campos da saúde, da educação e da economia popular. Isso, no entanto, não impediu nem o surgimento do movimento indígena TIPNIS, em 2011, nem os protestos sociais contra a 'gasolina' de 2010, e nem o desenvolvimento e crescimento de movimentos sociais verdadeiramente anticapitalistas, como o Movimento Pachacutik, de Felipe Quispe, todas essas expressões da continuação da validade e força da economia moral da multidão boliviana, que mais uma vez se condensaram e se tornaram presentes nas vastas mobilizações populares contra a fraude eleitoral de 2019, que causou a queda de Evo Morales, e que ainda está vigiando o resultado final dessa atual crise, diante do governo de direita oportunista e não representativo de Jeanine Añez e diante da emergência mundial da pandemia do novo coronavírus.

E se os índios aimarás, de maneira semelhante aos neo-zapatistas e também a outros povos indígenas espalhados por toda a extensão da América Latina, conseguiram manter com sucesso uma parte importante de suas linhas civilizadoras, alheias e às vezes opostas ao projeto da modernidade capitalista que as elites dominantes bolivianas tentam impor a eles a cinco séculos, construindo, a partir dessas linhas civilizadoras, um caminho diferente de modernização, e também uma modernidade, em primeiro lugar, de resistência e, consequentemente, alternativa à atual modernidade capitalista. Então, é claro que essa modernidade, divergente da capitalista, também alimenta, na longa duração histórica, a economia moral das classes subordinadas bolivianas e, a partir dela, a oposição anticapitalista que amadureceu e se organizou progressivamente, primeiro contra o governo socialdemocrático morno, totalmente pró-capitalista, de Evo Morales, e então e até agora, enfrentando o governo vazio, frágil, ilegítimo e oportunista de Jeanine Añez ${ }^{17}$.

Algo semelhante ao que aconteceu no Equador, onde, sob os governos de Rafael Correa, e em comparação com os grandes surtos sociais e as vastas mobilizações que

\footnotetext{
${ }^{17}$ Sobre os pontos mencionados e sobre a crise desencadeada pela fraude eleitoral de 2019, cf. os seis números da revista anual Willka, publicados entre 2008 e 2013, o livro coletivo La MAScarada del Poder, Ed. Herramienta Ediciones, Buenos Aires, 2012, as entrevistas com Felipe Quispe, "Bolivia en la encrucijada", em Contrahistorias, n. 12, 2009, e "Entrevista sobre la situación actual de Bolivia", em Contrahistorias, n. 26 de 2016 e Luis Tapia, "Crisis Política en Bolivia. La coyuntura de disolución de la dominación masista", em http://www.cides.edu.bo/webcides2/index.php/interaccion/noticias-f/264-crisis-politica-en-bolivia-la-coyunturade-disolucion-de-la-dominacion-masista.
} 
caracterizaram o período dos anos entre 1990 e 2005, ou seja, entre as primeiras grandes revoltas indígenas e a "revolução fora da lei" que derrubou Lucio Gutiérrez, a economia moral das multidões equatorianas parecia adormecer um pouco em termos de manifestações mais visíveis e fortes, a partir da divisão interna da CONAIE, e de certa fragmentação e localização dos movimentos de protesto, que além de serem perseguidos e criminalizados pelo próprio Correa, também foram parcialmente desativados por meio de concessões econômicas neokeynesianas moderadas e pelas políticas social-democráticas mornas que, como no caso de todos os chamados governos 'progressistas' da América Latina, implementaram, por sucessivos governos, a chamada 'Revolução Cidadã' no Equador. Isso não impediu o setor amazônico do CONAIE, entre outros grupos populares, de manter sempre uma atitude crítica e anticapitalista de protesto contra esses governos, diante de Rafael Correa e depois o 'renegado' Lenin Moreno.

E se durante os governos de Rafael Correa, essa economia moral do povo subordinado da Bolívia pareceu desacelerar um pouco, ela reapareceu com nova força nos recentes protestos populares de outubro de 2019, quando praticamente todos os setores populares e subordinados do Equador se levantaram contra o Decreto 883 e o 'pacote' neoliberal de Lenin Moreno, que aumentaram o preço da gasolina e do diesel, impuseram reformas trabalhistas agressivas contra os trabalhadores e deram novos benefícios e isenções aos empregadores. Medidas que conseguiram reunir todos os movimentos antigos, trabalhadores, camponeses e indígenas, mas também movimentos mais recentes, como o movimento feminista, o movimento juvenil que vai além do próprio movimento estudantil, ou movimentos dos habitantes das periferias de Quito e outras cidades importantes no Equador.

A mobilização vasta e combativa do povo equatoriano, realizada entre 2 e 13 de outubro de 2019, que, além de ter alcançado uma vitória importante e clara, conseguindo a revogação do Decreto 833 e das medidas da parcela, mostrou a profunda fraqueza e ilegitimidade do governo Moreno, encurralando-o e forçando-o a fugir para Guayaquil, em face da demonstração da enorme força e poder dos subordinados, e em face desse novo avivamento e manifestação vigorosa da economia moral das multidões equatorianas, mais uma vez despertada e ativa. Uma economia moral que, então, poderia, em breve, provocar novos levantes ou insurreições populares, ou novos levantes indígenas, ou ambos combinados, em um futuro muito próximo ${ }^{18}$.

\footnotetext{
${ }^{18}$ Nesta insurreição popular equatoriana, cf. Miguel Merino S., "Balance de la insurrección popular en Ecuador", em La línea de fuego. Revista Digital, de 30 de dezembro de 2019, em: https://lalineadefuego.info/2019/12/30/balance-de-la-insurreccion-popular-en-ecuador-por-miguel-merino-s/
} 
E é importante ressaltar que, no Equador, como no México e na Bolívia, ou no setor mais radical do movimento mapuche chileno, entre outros casos, há também uma modernidade diversificada de resistência e alternativa à capitalista, que alimenta a economia moral das multidões indígenas equatorianas, sendo uma das fontes de suas posições radicalmente anticapitalistas e anti-sistêmicas. Isso é evidente, para citar apenas um exemplo possível, na concepção indígena de 'sumak kawsay' ou 'boa vida' - equivalente ao suma qamaña aymara sum -, uma concepção antipodal às noções capitalistas de 'desenvolvimento' , de 'crescimento' e 'progresso', sempre orientadas com uma lógica predominantemente quantitativa e governadas pelo desejo de acumular cada vez mais bens, riquezas e objetos, sem limite e sem medida, persegue, por sua vez, a construção qualitativa de uma vida equilibrada e em harmonia com a natureza, com outros seres humanos e com todo o ambiente.

Noção indígena de boa vida, que não deseja a acumulação ilimitada de bens, mas apenas os bens necessários para viver bem, e que não busca submeter totalmente a natureza ao ser humano e dominá-la como seu mestre, mas respeitá-la, cuidá-la e reproduzi-la harmoniosamente, ao concebê-la como 'Mãe Terra', como a fonte e a origem da própria vida humana e da vida em geral. Uma concepção radicalmente diferente da concepção capitalista, pois não deseja explorar outros seres humanos, competir com eles ou tirar proveito dos encontros ou elos que eles estabelecem com eles, mas respeitá-los e concebê-los como iguais, buscando a harmonia e o equilíbrio dos vínculos com eles construídos ${ }^{19}$.

A economia moral da multidão, que também se manifestou, claramente, no Brasil, nos últimos anos, em resposta, por exemplo, à queixa de investir milhões e milhões de dólares na Copa do Mundo de 2104, que só beneficiava as empresas imobiliárias brasileiras e as empresas ligadas ao futebol, em vez de investir em hospitais, escolas ou em melhor transporte para todo o povo brasileiro. Ou, também, como reação aos repetidos ataques que, nos últimos anos, tentaram, várias vezes, aumentar as tarifas de transporte público, já caras e que constituem um elemento importante da economia popular. Isto gerou o Movimento Passe Livre e as vastas mobilizações que ele desenvolveu em vários momentos importantes da história brasileira recente.

\footnotetext{
${ }^{19}$ Sobre a situação mais geral dos movimentos anticapitalistas e anti-sistêmicos no Equador, cf. a entrevista com Marlon Santi, "Un nuevo giro a la izquierda. La Confederación de Nacionalidades Indígenas del Ecuador", em Contrahistorias, n. 11, 2008. E com relação à concepção indígena de 'Bem Viver', deve-se dizer que é um conceito banalizado e adulterado a extremos caricaturais, até o ponto de que, agora, figura nas Constituições Nacionais da Bolívia e do Equador, mas em uma versão que, absurdamente, a iguala às noções capitalistas de desenvolvimento, progresso e crescimento econômico. Sobre esse conceito, veja o trabalho, desigual, mas útil, de Fernando Huanacuni Mamani, Buen Vivir/Vivir bien. Filosofía, políticas, estrategias y experiencias regionales andinas, Ed. Coordinadora Andina de Organizaciones Indígenas, Lima, 2010.
} 
Mas, também, e em um nível mais profundo, a economia moral das multidões brasileiras é alimentada por uma realidade duradoura que é a estrutura agrária muito atrasada do Brasil, que nunca viveu o processo urgente e saudável de uma verdadeira Reforma Agrária, fazendo com que a concentração da posse de terra, no país, seja desproporcionalmente alta e o maior proprietário de terras do planeta seja brasileiro, possuindo terras superiores, em tamanho, aos territórios da Bélgica e da Holanda juntos. Este é um dos fatores que, além disso, faz do Brasil um dos países mais desiguais do mundo.

Por esse motivo, não é de estranhar que o poderoso Movimento dos Trabalhadores Rurais Sem Terra (MST) tenha se desenvolvido no Brasil, um movimento que expressa essa situação anômala, do país, da ausência histórica de uma Reforma Agrária, que teria democratizado, em alguma medida, o acesso à terra, e modernizado, de maneira importante, a atual sociedade e capitalismo brasileiros. Poderoso e vasto movimento do MST, que hoje cobre mais de 5 milhões de pessoas, e que se alimenta de uma economia moral das multidões brasileiras, marcada na longa duração histórica, por um profundo e estrutural anseio por terras, um desejo que não é apenas presente entre os camponeses ou entre a população rural do Brasil, mas também é compartilhado por amplos setores dos pobres urbanos desta imensa nação sul-americana.

E, da mesma maneira que, somente na Argentina, há movimentos de 'trabalhadores desempregados', que, neste caso, expressam o direito histórico simbólico único ao trabalho que as classes subordinadas argentinas forjaram em sua história particular, também é somente no Brasil que existe um peculiar movimento de camponeses ou trabalhadores rurais 'sem terra', uma frase que também é um grande oximoro, e que reflete, basicamente, essa anomalia histórica especificamente brasileira de um país imenso que, contra a corrente de todos os seus vizinhos, nunca teve uma verdadeira e radical reforma agrária abrangente.

O que moldou, nos registros da longa duração da história brasileira, uma espécie de profundo desejo que, até agora, não foi cumprido pelo secular e milenar 'direito à terra', aqui assumido não apenas pelos camponeses e trabalhadores rurais, mas, também, por todo o conjunto de classes, grupos e setores subordinados deste imenso país. Ao recusar-se a realizar essa reforma agrária radical urgente e impostergável, as classes dominantes brasileiras estão dando passos rápidos para um possível e quase grande surto social no Brasil, que, sem dúvida, expressará, também, esse profundo desejo histórico à terra, constitutiva da economia moral das multidões brasileiras.

Um 'direito histórico à terra' único, que, embora presente em muitas outras nações do mundo, no Brasil é aguçado e diferenciado de maneira muito particular, devido ao fato 
realmente escandaloso e inexplicável de que, em meados do século XXI, ainda permanece pendente, nesta enorme e fundamental nação sul-americana, de indiscutível relevância latinoamericana e até mundial, a realização de uma verdadeira reforma agrária radical, profunda e orgânica. Trata-se de uma grande pendência histórica que não foi resolvida ou seriamente empreendida, nem pelos governos Lula, e muito menos por Dilma Roussef, e que talvez seja uma das causas importantes que causaram a erosão e a deslegitimização dos governos emanados do Partido dos Trabalhadores (PT) brasileiro, abrindo, assim, a porta para o retorno da direita brasileira não representável, primeiro com o terrível e regressivo governo de Michel Temer, e, agora, com o governo realmente vergonhoso e catastrófico de Jair Bolsonaro ${ }^{20}$.

$\mathrm{O}$ direito único e muito específico de trabalhar, na Argentina, e o direito à terra, no Brasil, que, nos casos mencionados no México, Bolívia e Equador, têm seu equivalente no singular e, em cada caso, diferenciados de 'direito a uma modernidade diferente', que, a partir das ideias de respeito à Mãe Terra, da predominância do coletivo sobre o individual, do Bem Viver, da democracia direta e da assembleia, entre outras, também determina as economias morais particulares da multidão de cada uma das referidas nações.

Como vemos nos exemplos até agora mencionados, há, claramente, uma sobreposição multitemporal complexa dessa economia moral das multidões latino-americanas, que alimenta e reproduz o mesmo com as recentes queixas e ataques das classes dominantes que, com suas ofensas e abusos, se arrastam por décadas ou séculos. Isso também se reflete, por exemplo, no fato de que os novos movimentos anti-sistêmicos da América Latina tomam, tomam tal superposição dessa economia como referência simbólica fundamental para a ação, as suas práticas, as suas reivindicações e a reivindicação de seus objetivos gerais; o mesmo se passa com relação à figura de Che Guevara, ou à de Emiliano Zapata, à personagem de Tupac Katari, ou de Lautaro, as quais são baseadas nos princípios derivados da compreensão da terra como "Pachamama" ou "Mãe Terra"21 ou, no da já mencionada concepção do "Sumak Kawsay" ou "Bem Viver", típico das visões de mundo indígenas. As referências centrais desses movimentos, que ilustram o fato de que suas raízes e determinações essenciais se referem, igualmente, às lutas latino-americanas dos anos 1950 e 1960, bem como à Revolução

\footnotetext{
${ }^{20}$ Sobre essa singularidade do caso brasileiro e sua economia moral específica da multidão, cf. João Pedro Stedile, Brava gente. La lucha de los sin tierra en Brasil, Ed. Desde Abajo, Bogotá, 2003, Aleida Guevara, MST. MST. Simiente de la vida y la esperanza, Ed. Ocean Sur, México, 2009, Sue Branford e Jan Rocha, Rompendo a cerca. A historia do MST, Ed. Casa Amarela, São Paulo, 2004, e Mitsue Morissawa, A história da luta pela terra e o MST, São Paulo, 2001.

${ }^{21}$ Sobre a importância e as múltiplas implicações e suposições que essa concepção complexa e sutil da terra como "Mãe Terra" implica, veja nosso ensaio, Carlos Antonio Aguirre Rojas, "Latin America's Antisystemic Movements and Its Struggle for the Land in the Twenty-First Century", em Review, vol. XXXIII, número 4, 2010.
} 
Mexicana de 1910-1921, mas também às lutas e rebeliões bolivianas do século XVIII, ou aos princípios indígenas pré-hispânicos que conseguiram manter e preservar, apesar de modernizá-los e modificá-los, após as invasões e conquistas espanhola e portuguesa ${ }^{22}$.

A complexidade multidimensional dessa economia moral das multidões, nos diferentes países da América Latina, que, ao mesmo tempo em que nos ilustra as muitas e diversas dificuldades envolvidas em conseguir apreender, com precisão e adequação, a dinâmica específica do comportamento dos setores, grupos e classes subalternas, e também dos movimentos sociais que elas constituem, também nos mostram a fertilidade e a riqueza específica dessa ampla faixa metodológica e epistemológica, descoberta, cultivada e elaborada por Edward Palmer Thompson e sintetizada em esse conceito brilhante de "economia moral da multidão".

Pista metodológica particularmente frutífera, que por esse motivo e não por coincidência, foi recuperada, da mesma forma, para explicar as rebeliões camponesas na Birmânia ou no Vietnã, no sudeste da Ásia, ou os conflitos trabalhistas na indústria automobilística estadunidense, que o método de "desrespeito", desenvolvido na piquetera Argentina dos últimos cinco anos, e também concebida, e muito mais amplamente, como um dos mecanismos explicativos gerais do vasto conjunto de formas de protesto social ao longo da história do capitalismo mundial. E entre muitas outras aplicações, ele também passou por vários usos, incluindo sua reivindicação como uma ferramenta analítica para explicar a Revolução Mexicana, ou sua expansão para outros períodos, outras latitudes e outras figuras do mesmo protesto camponês, na Inglaterra, Nigéria, Costa Rica, Nicarágua, Bolívia, Irlanda e Índia ${ }^{23}$.

E também, logicamente, essa rica pista epistemológica revela-se singularmente útil e heurística, quando observamos como todos esses novos movimentos anti-sistêmicos da

\footnotetext{
${ }^{22}$ Sobre as formas complexas pelas quais essa Revolução Mexicana ainda está presente no imaginário popular das classes subordinadas mexicanas, cf. Carlos Antonio Aguirre Rojas, Mitos y Olvidos en la Historia Oficial de México, Ed. Quinto Sol, 3a. edição, México, 2007, e Contrahistoria de la Revolución Mexicana, Ed. Universidad Michoacana, 2a. edição, Morelia, México, 2011. Sobre as rebeliões bolivianas do século XVIII e sobre suas presenças ainda em vigor, cf. Silvia Rivera Cusicanqui, Oprimidos pero no vencidos, Ed. La Mirada Salvaje, La Paz, 2010. Sobre a preservação complicada dos princípios indígenas e suas várias formas de sobrevivência, cf. Andrés Aubry, Chiapas a contrapelo, Ed. Contrahistorias, México, 2005.

${ }^{23}$ Para todos esses exemplos mencionados, e seguindo a ordem em que estão listados aqui, cf. James C. Scout, The Moral Economy of the Peasant: Rebellion and Subsistence in Southeast Asia, Ed. Yale University Press, New Haven, 1976; Carl Gersuny e Gladys Kaufman, "Seniority and the Moral Economy of U.S. Automobile Workers, 1934-1946", no Journal of Social History, n XVIII, 1985; Raúl Zibechi, Genealogía de la revuelta. Argentina: La sociedad en movimiento, Ed. FZLN, México, 2004; Carlos Antonio Aguirre Rojas, "Planeta tierra: los movimientos antisistémicos hoy", no livro de Immanuel Wallerstein, Historia y dilemas de los movimientos antisistémicos, Ed. Contrahistorias, México, 2008; Alan Knight, "Armas y arcos en el paisaje revolucionario mexicano", em Aspectos cotidianos de la formación del Estado, Ed. Era, México, 2002, e finalmente os trabalhos citados pelo próprio Thompson em seu ensaio "A economia moral revisada", citadas acima, e especialmente as notas 2, 13, 14, 19, 204, 205, 213, 217, 218, 219 e 220.
} 
América Latina ${ }^{24}$ apoiam e nutrem o conjunto de suas ações concretas, em um húmus multifacetado onde coexistem referências à contramemória popular (que convoca Francisco Villa, Bartolina Sisa, Rumiñahui, Camilo Torres ou Chico Mendes), ou costumes profundos e tradições densamente enraizadas (como a ideia de um direito natural dos camponeses à terra ou de certos pobres urbanos para trabalhar, ou o coletivo indígena 'nós' acima do eu individualista ocidental, ou a visão ética do que é uma "vida simples e correta"), com os códigos sempre muito animados e ativos da cultura plebe subalterna (que zomba dos ricos e deprecia todos os tipos de autoridade, desconfiando de todos os tipos de hierarquias e sempre reivindicando uma lógica niveladora, humorística e libertária) ${ }^{25}$, ou com instinto rebelde da obrigação de enfrentar as queixas das classes e grupos hegemônicos (a partir do repertório renovado e inesgotável de respostas, ações, manifestações e formas de protesto que são sempre improvisadas e/ou planejadas e organizadas pelos setores subordinados da sociedade), ou seja, daquele húmus que é precisamente o da economia moral da multidão.

Essa é uma pista especialmente útil e ainda proveitosa para a análise da América Latina hoje e dos movimentos anti-sistêmicos que ela abriga, e das lutas sociais que ela está liderando agora, que não podem ser totalmente entendidas e compreendidas se permanecermos exclusivamente dentro do campo do conhecimento acadêmico, erudito e puramente teórico. Pois se essa economia moral da multidão nasce e forja da tradição, dos costumes, do instinto rebelde e da cultura plebeia das classes e dos grupos sociais subalternos, fica claro que aqueles que a conhecem melhor são os mesmos setores dominados e explorados, do fundo da pirâmide social.

E é a eles, então, que devemos ouvir e observar, e com os quais todos devemos aprender, como recomendaram nossos colegas neo-zapatistas, em várias ocasiões e ao longo de sua história, por exemplo: de maneira especialmente enfática, no Seminário 'Pensamento Crítico contra a Hidra capitalista' do ano de 2015. Bem, é desses setores e classes subordinadas, dos quais analistas e cientistas sociais realmente críticos devemos aprender, com paciência e modéstia, para poder, a partir do vínculo com eles e do compromisso de acompanhar suas experiências e lutas, tentar reconhecer e reconstruir, com cuidado, os perfis

\footnotetext{
${ }^{24}$ Sobre algumas das principais características que assinalam esses novos movimentos anti-sistêmicos na América Latina atualmente, cf. Carlos Antonio Aguirre Rojas, "Les nouveaux mouvements sociales en Amérique Latine. Una brève radiographie générale”, in Review, vol. XXXI, número 1, 2008 e Movimientos antisistémicos y cuestión indígena en América latina, já mencionados acima.

${ }^{25}$ Sobre esses traços da cultura popular, cf. Mikhail Bakhtin, La cultura popular en la Edad Media y en el Renacimiento. El caso de François Rabelais, Ed. Alianza Editorial, Madri, 1990, e todos os seus ensaios incluídos na edição 30 da revista Contrahistorias, 2018. Cf. também Carlos Antonio Aguirre Rojas, "Mikhail Bakhtin's Lessons on the Codes of Popular Culture", no livro Lessons in Critical Theory, Ed. Peter Lang, Nova York, 2020.
} 
específicos e singulares das muitas vezes mencionadas e sempre essenciais, economias morais das diversas multidões latino-americanas.

Perfis específicos da economia moral da multidão latino-americana que, em virtude do papel da vanguarda mundial, hoje detida por esses movimentos sociais anti-sistêmicos em toda a América Latina, tornam-se especialmente relevantes para todo o conjunto de movimentos anti-sistêmicos de todo o planeta. Como esses movimentos anti-sistêmicos, que hoje povoam a geografia do semi-continente latino-americano, não apenas antecipam parte do futuro possível dos outros movimentos anticapitalistas do mundo, mas também já fizeram, a partir de agora e de seus próprios espaços, tentativas de começar a construir mundos novos não capitalistas. Novos mundos que, por enquanto apenas em escala reduzida e experimentalmente, mas muito bem estabelecidos e evidentes, já estão prosperando nos 'Caracoles' neo-zapatistas de Chiapas, ou nos bairros piqueteros da Argentina, ou nos acampamentos e assentamentos dos Sem-Terra Brasileiros, bem como nas comunidades indígenas verdadeiramente rebeldes da Bolívia, Equador e Chile, entre outras.

Como se apresenta, então, a atual América Latina, vista sob as lentes específicas do conceito thompsoniano de economia moral da multidão? Em termos gerais, e mantendo todas as proporções do caso, poderíamos dizer que essa América Latina do terceiro milênio cronológico é, hoje, o equivalente histórico do que foi a Europa revolucionária da segunda metade do século XIX.

Porque se compararmos, cuidadosamente, essa Europa revolucionária da vida de Marx, com a América Latina de hoje, veremos, facilmente, como uma série de elementos e indicadores fundamentais se repete nos dois casos. Por exemplo, o papel de vanguarda mundial que já mencionamos, de cada um desses espaços, em relação às lutas anti-sistêmicas mais avançadas de seus respectivos tempos. E se, entre 170-130 anos atrás, o movimento trabalhista europeu foi o agente revolucionário por excelência e, ao mesmo tempo, o movimento trabalhista mais robusto, desenvolvido, lúcido e poderoso do mundo, hoje, os movimentos anti-sistêmicos da América Latina, movimentos plurais e diversos de todos os grupos, setores e classes subordinadas da sociedade, também são o novo e incontestado agente revolucionário, sendo, ao mesmo tempo, os movimentos mais fortes, avançados e experimentais e combativos de todo o mundo. 
E se a Europa revolucionária da segunda metade do século XIX engendrou a perspectiva rica e ainda válida do pensamento marxista crítico, a América Latina atual está começando a gerar, agora, as novas e mais avançadas teorias sociais e políticas de todo o planeta, as quais, conectando-se ao marxismo e estendendo-o às condições atuais, alimentamse para crescer e se desenvolver, precisamente a partir dessas experiências ricas e complexas de todos esses novos movimentos anticapitalistas e anti-sistêmicos da América Latina.

E se, no período de 1848-1917, a Europa viveu claramente o processo no qual o termômetro da economia moral da multidão europeia começava a ferver, e os surtos das revoluções europeias de 1848, ou da Comuna de Paris, multiplicaram-se em 1871, assim como os das revoluções alemã e húngara (e até russa) dos tempos da Primeira Guerra Mundial, também hoje a América Latina vive aquele maior aquecimento e fervura da economia moral de suas diferentes multidões, que, hoje, florescem e explodem, de maneira criativa e radical, em Santiago do Chile, Quito ou Bogotá, enquanto se manifestam e estão bem presentes em Cochabamba, El Alto, La Paz ou Manágua, mas, também, em San Cristóbal de Las Casas, em Buenos Aires, em Caracas ou em São Paulo, e que, amanhã, talvez o façam, igualmente, em Lima, Guatemala, San Salvador ou Cidade do México, entre muitos outros pontos de sua diversa, plural e possível irrupção.

Embora, com uma diferença radical. Pois, se o resultado final daquele ciclo de erupções violentas da economia moral da multidão europeia, naquela segunda metade do século XIX, desencadearia duas guerras mundiais, que afogaram o impulso revolucionário nos processos trágicos do nazismo, do fascismo e do franquismo, agora, essa nova manifestação da economia moral da multidão, nos espaços gerais da América Latina, se desenrola no contexto claro da crise terminal do sistema capitalista mundial. E, com isso, dentro de um contexto muito mais favorável e propiciatório, e também muito mais promissor do que o de 170-100 anos atrás.

Por esse motivo, e sendo tenazmente otimistas, pensemos que o resultado dessa nova rebelião recente, na América Latina, apoiada e alimentada, entre outros elementos, por essa economia moral de suas multidões, será, antes, contribuir para o fim histórico definitivo do capitalismo mundial, e igualmente, ao processo concomitante de construção de um mundo novo, não capitalista e não pré-histórico, que, como dizem os camaradas neo-zapatistas, será, sem dúvida, "um mundo onde muitos mundos se encaixam".

O que também, sem dúvida, segue a mesma linha do espírito profundo que sempre animou Edward Palmer Thompson, nos diferentes momentos em que ele descobriu, cultivou 
com paciência e cuidado, e sistematizou e poliu esse, seu principal conceito, que era o da economia moral da multidão.

\section{Referências bibliográficas}

ALMARAZ, Alejandro et al. La MAScarada del Poder. Ed. Herramienta Ediciones, Buenos Aires, 2012.

AUBRY, Andrés. Chiapas a contrapelo. Ed. Contrahistorias, México, 2005.

BAKHTIN, Mikhail. La cultura popular en la Edad Media y en el Renacimiento. El caso de François Rabelais. Ed. Alianza Editorial, Madri, 1990.

BRANFORD, Sue; ROCHA, Jan. Rompendo a cerca. A historia do MST. Ed. Casa Amarela, São Paulo, 2004.

BRAUDEL, Fernand. Historia y ciencias sociales. La larga duración. In: Escritos sobre historia. Ed. Fondo de Cultura Económica, México, 1991.

CARPENTIER, Alejo. De lo real maravilloso latino-americano. Ed. UNAM, México, 2004. CUSICANQUI, Silvia Rivera. Oprimidos pero no vencidos. Ed. La Mirada Salvaje, La Paz, 2010.

ECHEVERRÍA, Bolívar. Las ilusiones de la modernidade. Ed. UNAM - Ed. The Equilibrista, México, 1995.

ECHEVERRÍA, Bolívar. La modernidad de lo barroco. Ed. Era, México, 1998.

ENRÍQUEZ, Miguel. Miguel Enríquez y el proyecto revolucionario en Chile. Discursos y documentos del Movimiento de Izquierda Revolucionaria. Coedição do Centro de Estudos Miguel Enríquez-Ed. LOM, Santiago do Chile, 2004.

ENRÍQUEZ, Miguel. Movimiento de Izquierda Revolucionaria. Textos escogidos 19701975. Ed. Del MIR, Santiago do Chile, 1978.

ENRÍQUEZ, Miguel. En el camino del poder popular. Serie del Poder Popular. Ediciones El Rebelde, Santiago do Chile, agosto de 1973.

GERSUNY, Carl; KAUFMAN, Gladys. Seniority and the Moral Economy of U.S. Automobile Workers, 1934-1946. Journal of Social History, $n^{\circ}$ XVIII, 1985;

GUEVARA, Aleida. MST. Simiente de la vida y la esperanza. Ed. Ocean Sur, México, 2009. KNIGHT, Alan. Armas y arcos en el paisaje revolucionario mexicano. In: Aspectos cotidianos de la formación del Estado. Ed. Era, México, 2002.

MAMANI, Fernando Huanacuni. Buen Vivir/Vivir bien. Filosofía, políticas, estrategias y experiencias regionales andinas. Ed. Coordinadora Andina de Organizaciones Indígenas, Lima, 2010.

MAZZEO, Miguel. Piqueteros. Breve historia de un movimiento popular argentino. Ed. Quadrata, Buenos Aires, 2014.

MERINO, Miguel. Balance de la insurrección popular en Ecuador". La línea de fuego. Revista Digital, 30 de dezembro de 2019 Disponível em: https://lalineadefuego.info/2019/12/30/balance-de-la-insurreccion-popular-en-ecuador-pormiguel-merino-s/ 
MONSIVÁIS, Carlos. Aires de familia: cultura y sociedad en América Latina. Ed. Anagrama, Barcelona, 2000.

MORISSAWA, Mitsue. A história da luta pela terra e o MST. São Paulo, 2001.

PACHECO, Mariano. De Cutral-Có a Puente Pueyrredón. Una genealogía de los Movimientos de Trabajadores Desocupados. Ed. El Colectivo, Buenos Aires, 2010.

ROJAS, Carlos Antonio Aguirre. América Latina en la encrucijada. Ed. Contrahistorias, $7^{\mathrm{a}}$ edição, México, 2009;

ROJAS, Carlos Antonio Aguirre. América Latina. História e presente. Ed. Papirus, São Paulo, 2004;

ROJAS, Carlos Antonio Aguirre. Antimanuel du bon rebele. Ed. L'Harmattan, Paris, 2015

ROJAS, Carlos Antonio Aguirre. Braudel, o mundo e o Brasil. Cortez Editora, São Paulo, 2003.

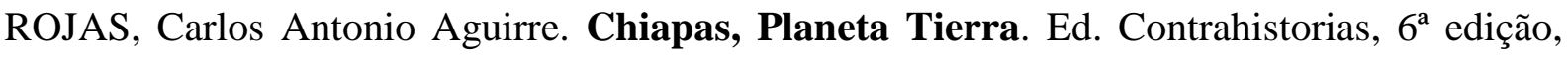
México, 2010.

ROJAS, Carlos Antonio Aguirre. Chile insurrecto en 2019 y 2020: el Derecho de Vivir en Rebeldía. Contrahistorias, n. 33, 2020.

ROJAS, Carlos Antonio Aguirre. Contrahistoria de la Revolución Mexicana. Ed. Universidad Michoacana, 2a. edição, Morelia, México, 2011.

ROJAS, Carlos Antonio Aguirre. Edward Palmer Thompson e a 'economia moral da multidão' no mundo do século XXI. In: Pensadores críticos del 'longo século XX'. Ed. Public University, de El Alto, El Alto, Bolívia, 2018.

ROJAS, Carlos Antonio Aguirre. Fernand Braudel e as ciências humanas. Editora da Universidade Estadual de Londrina, Londrina, 2003.

ROJAS, Carlos Antonio Aguirre. La cuestión indígena en México y en América Latina. Una visión desde la larga duración histórica. Contrahistorias, n. 28/29, 2018.

ROJAS, Carlos Antonio Aguirre. La modernidad de lo barroco. Editora Entremares, São Paulo, 2019.

ROJAS, Carlos Antonio Aguirre (orgs.). La revolución cultural mundial de 1968. Ed. Desde Abajo, Bogotá, 2018.

ROJAS, Carlos Antonio Aguirre. La revolución mundial de 1968. Cuatro décadas después. Contrahistorias, n. 11, México, 2008.

ROJAS, Carlos Antonio Aguirre. Latin America's Antisystemic Movements and Its Struggle for the Land in the Twenty-First Century. Review, vol. XXXIII, número 4, 2010.

ROJAS, Carlos Antonio Aguirre. Les nouveaux mouvements sociales en Amérique Latine. Una brève radiographie générale. Review, vol. XXXI, número 1, 2008.

ROJAS, Carlos Antonio Aguirre. Mikhail Bakhtin's Lessons on the Codes of Popular Culture. In: Lessons in Critical Theory, Ed. Peter Lang, Nova York, 2020.

ROJAS, Carlos Antonio Aguirre. Mitos y Olvidos en la Historia Oficial de México. Ed. Quinto Sol, 3a. edição, México, 2007.

ROJAS, Carlos Antonio Aguirre. Movimenti antisistemici. Pensare un'alternativa no XXI secolo, Ed. Aracne Editrice, Roma, 2013;

ROJAS, Carlos Antonio Aguirre. Movimientos antisistémicos y cuestión indígena en América Latina. Ed. Quimantú, Santiago do Chile, 2018.

ROJAS, Carlos Antonio Aguirre. Planeta tierra: los movimientos antisistémicos hoy. In: WALLERSTEIN, Immanuel. Historia y dilemas de los movimientos antisistémicos. Ed. Contrahistorias, México, 2008.

ROJAS, Carlos Antonio Aguirre. Tempo, duração e civilização. Percursos Braudelianos. Cortez Editora, São Paulo, 2001.

ROJAS, Carlos Antonio Aguirre. Una tenera furia. Nuovi saggi sul neozapatismo mexicano. Ed. Aracne Editrice, Roma, 2019. 
SANTI, Marlon. Un nuevo giro a la izquierda. La Confederación de Nacionalidades Indígenas del Ecuador. Contrahistorias, n. 11, 2008.

SALAZAR, Gabriel. En el nombre del poder popular constituyente (Siglo XXI). Ed. LOM, Santiago do Chile, 2016.

SALAZAR, Gabriel. El poder nuestro de cada día. Ed. LOM, Santiago do Chile, 2016.

SALAZAR, Gabriel. El tipo de Asamblea Constituyente que se propone, no representa realmente la voluntad soberana del Pueblo. El Ciudadano, ano 15, n. 238, dezembro de 2019, pp. 4-6.

SCOUT, James. The Moral Economy of the Peasant: Rebellion and Subsistence in Southeast Asia. Ed. Yale University Press, New Haven, 1976.

STEDILE, João Pedro. Brava gente. La lucha de los sin tierra en Brasil. Ed. Desde Abajo, Bogotá, 2003.

SVAMPA, Maristella; PEREYRA, Sebastián. Entre la ruta y el barrio. La experiencia de las organizaciones piqueteras. Ed. Biblos, 2a. edição, Buenos Aires, 2004.

THOMPSON, Edward Palmer. A formação da classe operária na Inglaterra. Ed. Crítica, 2 volumes, Barcelona, 1989

THOMPSON, Edward Palmer. Costumes em comum. Ed. Crítica, Barcelona, 1995.

WALLERSTEIN, Immanuel; ARRIGHI, Giovanni; HOPKINS, Terence. "1989, the continuation of 1968". Review, vol. XV, não. 2, Binghamton, 1992.

ZIBECHI, Raúl. Genealogía de la revuelta. Argentina: La sociedad en movimento. Ed. FZLN, México, 2004.

ZIBECHI, Raúl. Los desbordes desde abajo. 1968 en América Latina. Ed. Autodeterminación, La Paz, 2018. 